Article

\title{
Impact of Trade Openness and Human Capital on Economic Growth: A Comparative Investigation of Asian Countries
}

\author{
Rabail Amna Intisar ${ }^{1}$, Muhammad Rizwan Yaseen ${ }^{1}$, Rakhshanda Kousar ${ }^{2}$, \\ Muhammad Usman ${ }^{1}$ (D) and Muhammad Sohail Amjad Makhdum 1,*(D) \\ 1 Department of Economics, Government College University Faisalabad, Punjab 38000, Pakistan; \\ rabiamna28@gmail.com (R.A.I.); rizwany2001@yahoo.com (M.R.Y.); usman399jb@gmail.com (M.U.) \\ 2 Institute of Agricultural and Resource Economics, University of Agriculture Faisalabad, \\ Punjab 38000, Pakistan; rakhshanda.kousar@uaf.edu.pk \\ * Correspondence: sohailmakhdum@gcuf.edu.pk
}

Received: 20 February 2020; Accepted: 1 April 2020; Published: 7 April 2020

check for updates

\begin{abstract}
The aim of this study is to analyze the impact of trade openness and human capital on economic growth in 19 Asian countries from 1985 to 2017. We selected two geographically distributed regions (Western and Southern Asia) based on difference in their GDP per capita. We applied the unit root tests to examine the level of stationarity and found that all variables were integrated at first difference. Kao and Fisher cointegration tests were employed and the results revealed the presence of a long-run relationship. We applied fully modified ordinary least square (FMOLS) and dynamic ordinary least square (DOLS) models to check the magnitude of the long-run coefficients among trade openness, human capital and economic growth. To investigate the direction of causality, we used a Dumitrescu and Hurlin (DH) causality test. The results indicated that trade openness and human capital have a significant and positive relationship while labor force participation has a negative effect on economic growth in Southern Asia, and in the case of Western Asia, the impact is positive. Foreign direct investment (FDI) has a negative and significant impact on GDP per capita (GDPPC) in Western Asia while it is positive and significant in Southern Asia; Total population (TPOP) has a negative impact on GDPPC in both regions. Furthermore, human capital has a positive and significant impact on trade openness in both panels. Meanwhile, labor force participation (LFP) has a positive and significant impact on trade openness in Southern Asia and a negative impact in the case of Western Asia. Trade openness and economic growth have bidirectional causality in Western Asia and unidirectional causality in Southern Asia. It also shows that human capital and economic growth have unidirectional causality in both regions.
\end{abstract}

Keywords: trade openness; FDI; human capital; education; labor force; economic growth and fully modified OLS

\section{Introduction}

Trade openness and human capital are the major factors affecting economic growth [1,2]. It does not only include buying and selling of goods and services, but it also helps to develop new technologies, flows of new ideas and knowledge. The concepts of trade openness and trade liberalization are the most debated topics in all economies. If a country moves toward trade openness, the economy is more likely to grow. The word openness means the absence of restrictions or a flexible attitude toward trading activities. Hence, trade openness refers to the degree to which a domestic country permits to trade with other countries. Trading activities usually include exports, imports, foreign direct investment (FDI), lending, borrowing, and repatriation of funds from abroad [3]. Trade openness also 
promotes growth in several ways. It increases capital formulation and expands markets through an increase in investment $[4,5]$. It creates enormous benefits to the country's industrial sectors through developing new methods of production and increases the level of employment by creating more job opportunities, and may lead to poverty reduction [6]. There are three tools to measure the ratio of trade openness: one of them is the ratio of total trade volume (import and export) to GDP [7]; the second is the ratio of import and export to total population [8], and finally it can be calculated on the basis of tariff rates. In the current economic scenario, no country can develop successfully without trade openness, investment, and the migration of people. Published literature explored the positive impact of labor productivity on trade openness $[9,10]$. Trade openness and FDI bring technological transformation in an economy and also help to enhance the human capital of that particular economy [11].

Human capital is also observed as a fundamental source of economic growth [12]. It enhances the total productivity level and potential earnings of the labor force [13]. Human capital is also estimated by skills, qualification, ability to create new products, and experience of labor [14]. An economy can enhance human capital by specialization and labor division, improvement in basic education, vocational training, encouragement to self-employment, and creating business opportunities $[15,16]$. It is also considered a very important factor for an economy and it helps to provide a highly skilled and innovative labor force that can utilize limited resources with efficiency, which increases the per capita income $[17,18]$. An efficient human capital also attracts FDI, which stimulates economic growth $[19,20]$.

Endogenous growth theory indicates that economic growth is the first and primary result of internal forces. In addition, the theory confirms the supremacy of knowledge, innovation, and human capital and their contribution to economic growth. This theory is also concentrated on the positive and spillover effects of knowledge, which ultimately lead an economy towards development [21]. However, after the failure of endogenous theory, a unified theory of growth was developed [22], which captures the fundamental phases-getting away from the Malthusian trap, emergence of human capital as the fundamental element of growth, the onset of the fertility decline, and the elements of the modern era of economic growth [23] - by exploring the interaction between human traits and economic growth.

Accordingly, the aim of this study is to investigate the substantial contribution of human capital and trade openness to the economic growth of Asian region. In this regard, the previous literature focused more on the country-specific and corporation level in exploring the vigorous relationships among variables of interest. Specifically, this study compares the economic growth of two different panels of Asian countries based on trade openness and economic growth. Moreover, as per our knowledge, unlike the previous literature, we also compared the panel of Southern and Western Asian countries in a growth model, as every country has different obstacles in the way of development and faces different circumstances due to flabby policies regarding resources and income individually. Furthermore, this research explores the comparison of granger causal relationships among candidate variables in these regions. At the end, we confer the policy suggestions relevant to human capital and a trade-growth model on the bases of estimated outcomes. To achieve the research objectives, this research will help to give policy suggestions and recommendations. Moreover, previous literature explored the impact of trade openness and human capital on economic growth. However, there is still limited literature that shows the relationship for Asian countries simultaneously and also compares their regions.

The remaining paper is structured as follows: Section 2 consists of a literature review related to trade openness, human capital, economic growth, and other control variables used in this investigation. The data information and empirical models are introduced in Section 3. Empirical strategies are discussed in Section 4. Section 5 concludes the results and discussions of the outcomes of these empirical models, and in the last section, conclusions and policy suggestions are described.

\section{Literature Review}

There are several studies on human capital, trade openness and economic growth in developed and underdeveloped countries. In this regard, Ogundari and Awokuse [24] conducted their study in 
35 sub-Saharan African countries and examined the impact of human capital on economic growth. The results showed that human capital had positive effects on economic growth. Another study was conducted for the comparison of developed and underdeveloped countries to investigate the threshold effect of human capital and economic growth. The results were estimated by using the generalized method of moments (GMM), which showed that human capital has a positive and significant impact on economic growth in both regions [25]. By contrast, Abdullah [26] found a negative relationship between education and economic growth in the case of Malaysia. This is not a new relationship in the literature due to some reasons. In relation to existing problems, several factors were mentioned in previous studies. First, education may not contribute to enhance the production level. Furthermore, it is not a factor of the production process. Additionally, Pritchett [27] suggested that ere is a high chance that several educated people might be involved in illegal activities that will reduce the economic growth. Another study proposed by Awan and Naseem [28] found that education expenditure has a significantly adverse association with economic growth, while health expenditure raised the economic growth.

Further, in the case of Pakistan, Dar Ahmad and Mehmood [29] found that trade openness and FDI have a positive impact on economic growth. Another valuable study investigated the impact of trade openness on the income level and economic growth of 115 developing countries. The results were estimated through the common correlated effects mean group (CCEMG), fully modified ordinary least square (FMOLS), and dynamic ordinary least square (DOLS) estimation approaches and found a positive and bidirectional relationship between trade openness and income level as well as with economic growth [30]. According to Alam and Sumon [31], trade openness and economic growth have a positive relationship with economic growth. The vector error correction model (VECM) revealed bidirectional causality between economic growth and trade openness. Agiomirgianakis et al. [32] investigated the impact of human capital on the economic growth in 93 countries. The results revealed that there was a positive and significant impact of human capital (level of education) on economic growth. In Organization for Economic Co-operation and Development (OECD) countries, Bassanini and Scarpetta [33] revealed a significant and positive association among human capital and economic growth. In another remarkable study in 100 developed and underdeveloped countries, Yanikkaya [34] confirmed a significant and positive relationship among trade openness and economic growth of underdeveloped countries by using fixed effect estimation. The same relationship was investigated through different methodologies that reached similar findings.

Chen and Gupta [35] found a positive relationship among trade openness and economic growth in Africa by using the GMM model for estimation. In Africa a positive association of education with GDP per capita was also found, and a negative effect of labor force on GDP was also revealed [36]. Similarly, Kasman and Duman [37] investigated a positive association between trade openness and economic growth in the case of European Union member and candidate countries.

Kong et al. [38] revealed that trade openness has a positive relationship with, and significantly improves the quality of, economic growth in china. In Southeast Europe, Fetahi [39] showed the impact of trade openness and economic growth. The results indicated a positive influence of FDI on economic growth as well as trade openness and GDP by using pooled ordinary least square (POLS) regression. Indian Ocean rim countries have a positive relationship between trade openness and economic growth, as found by Nowbutsing [40]. In Bangladesh, Adhikary [41] explored the relationship among FDI, trade openness, capital formulation, and economic growth, and the results showed that FDI and capital formulation affected the economic growth positively and significantly, while trade openness was adversely linked with economic growth. Another study proposed by Bibi et al. [42] explored a negative association between trade openness and economic growth. The outcomes of DOLS cointegration regression indicated that a $1 \%$ increase in trade openness would reduce economic growth by $1.091 \%$ due to exchange rate depreciation in particular economies. Furthermore, it was found that trade-related policies and economic growth have bidirectional causality, and similar results are found consistent in line with Vernon [43] and Findlay [44]. 
Hye and Lau [45] revealed that trade openness has a negative relationship with economic growth in the long run and a positive one in short-run. They also revealed that human capital and physical capital have a positive association with economic growth in the long run. In India, Karimzadeh and Karimzadeh [46] revealed a significant and positive relationship between trade and economic growth as well as human capital and economic growth. Zhang and Zhuang [47] conducted a study in China and found that tertiary education is more effective than primary education for economic growth. Matousek and Tzeremes [48] examined the asymmetric relationship of human capital on economic development and observed a nonlinear relationship between them. Findings of this study also expressed that asymmetric patterns are more pronounced under perfect mobility assumptions among skilled and unskilled workers. However, in Nigeria, Adelakun [49] showed a positive relationship between human capital development and economic growth.

Adu-Gyamfi el al. [50] conducted a study in nine West African countries to investigate the relationship among trade openness, inflation, and economic growth. Results revealed that trade openness and inflation significantly reduced the economic growth. In Asian countries, Bajwa and Siddiqi [51] confirmed that three countries have a negative and statistically significant relationship with GDP in the years 1972 to 1985, while it was positive for Pakistan, and from 1986 to 2007 all countries had a positive effect on economic growth. In the case of Economic Community of West African States (ECOWAS) countries, a significant and positive relationship between trade openness and economic growth was observed [52]. Another remarkable study by Nguyen [53] conducted in three Northeast Asian countries found that trade openness accelerates the level of economic growth. Additionally, trade openness has a unidirectional relationship with economic growth and a bidirectional causal relation with the exchange rate.

\section{Data and Empirical Model}

\subsection{Data}

A total of 19 countries of Southern and Western Asia were included in this study, keeping in view the availability of data over a time period from 1985 to 2017. This study is based on the comparative investigation of Asian countries categorized into two panels on the basis of differences in their GDP per capita. We selected Bangladesh, India, Pakistan, Iran, Nepal, Sri-Lanka, and Bhutan in Southern Asia; and Turkey, Iraq, Saudi Arabia, Lebanon, Israel, Cyprus, Oman, Georgia, Bahrain, Armenia, and Azerbaijan in Western Asia. Table 1 shows the description of the variables used in this study, extracted from the World Development Indicator (WDI).

Table 1. Description of variables.

\begin{tabular}{lll}
\hline Variables & Description & Unit of measurement \\
\hline GDPPC & GDP per capita & Constant LCU \\
HC & Tertiary education & Percentage of gross secondary school enrollment \\
UPOP & Urban population & Percentage of total population \\
TPOP & Total population & Total number of legal residents \\
LFP & Labor force participation & Rate of the total labor force, including ages 15 to 64 \\
TO & Trade openness & Ratio with GDP \\
FDI & Foreign direct investment & Net inflows (Bop, Current US\$) \\
\hline
\end{tabular}

\subsection{Empirical Models}

To investigate the impact of trade openness and human capital on economic growth, we constructed two models with different pairs: these models are structured as show in Equations (1) and (2).

$$
\begin{gathered}
L G D P P C=\beta_{0}+\beta_{1} L H C+\beta_{2} L L F P+\beta_{3} L U P O P+\mu_{1} \\
L G D P P C=\beta_{0}+\beta_{1} L H C+\beta_{2} L F D I+\beta_{3} L T P O P+\beta_{4} L T O+\mu_{2}
\end{gathered}
$$


In both models, LGDPPC is the log of GDP per capita used as a dependent variable, $\mu_{1}, \mu_{2}$ are the error terms of both models, and the description of other independent variables is given in Table 1. Trade openness also depends on these factors as shown in Equation (3):

$$
L T O=\beta_{0}+\beta_{1} L H C+\beta_{2} L F D I+\beta_{3} L T P O P+\beta_{4} L L F P+u_{3}
$$

In this model, the log of trade openness, which is normalized by GDP, is used as a dependent variable, $u_{3}$ is the error term of model $C$, and the description of other independent variables is given in Table 1.

\section{Estimation strategies}

\subsection{Unit Root Test}

We have applied Levin, Lin and Chu (LLC) [54], Im Pesaran and Shin (IPS) [55], and Maddala and Wu-Augmented Dickey Fuller (MW-ADF) [56] panel unit root tests to check the stationary level of variables. LLC can be assumed as the pooled panel unit root test, IPS allows heterogeneity in the value, and Maddala and Wu (MW) unit root tests were employed for the nonparametric approach. Figure 1 presents the systematic econometric procedure followed in the current study to investigate the influence of concerned variables on economic growth and trade openness.

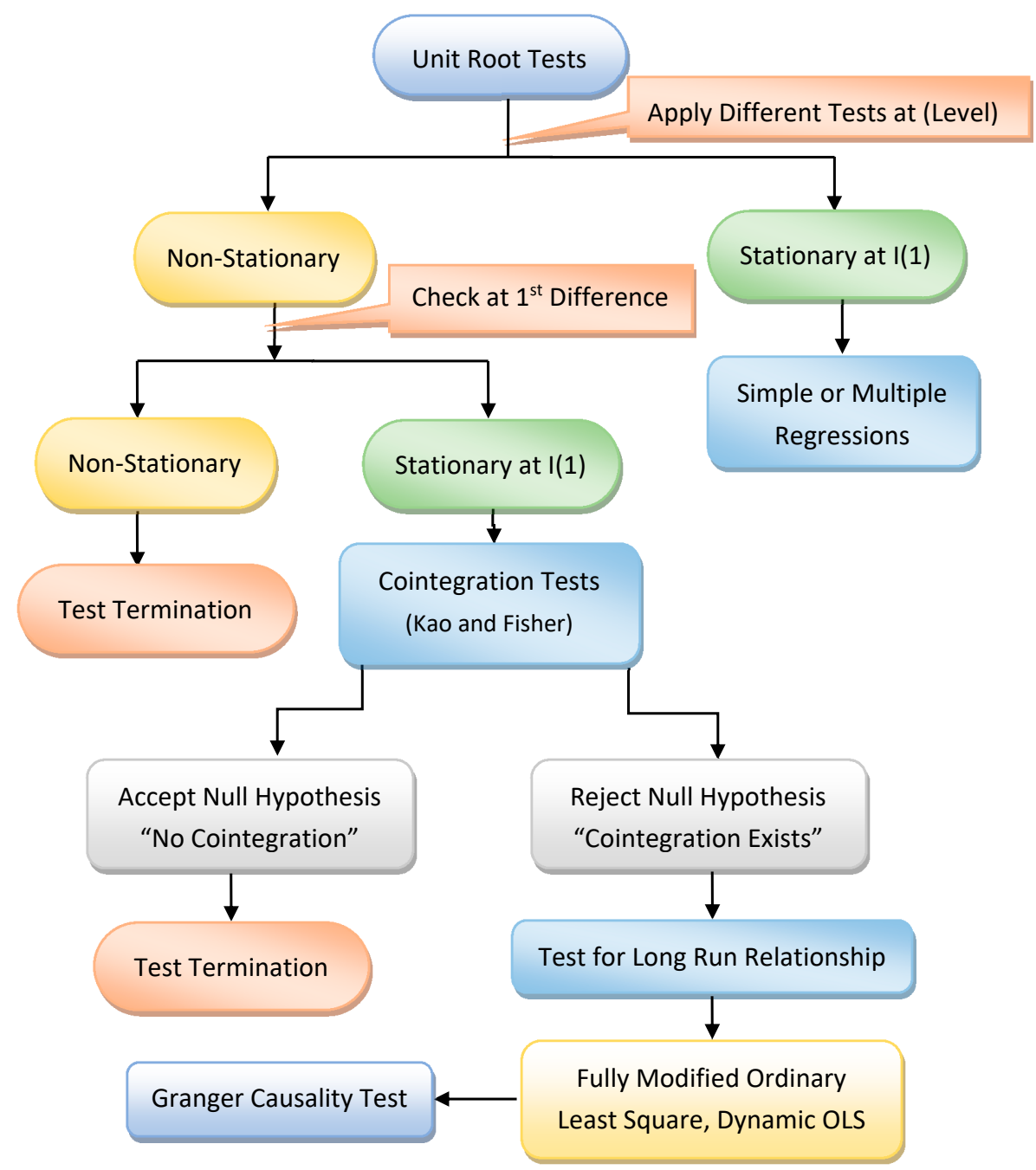

Figure 1. Systematic Econometric Process of Research. 


\subsubsection{LLC Unit Root Test}

LLC homogeneously represents autoregressive coefficients that indicate the absence or presence of the unit root problem. LLC investigates the unit root problem through ADF regression. There are three steps of the LLC test; first, for each cross-section a different ADF regression is applied, as shown in Equation (4):

$$
\Delta Y_{i t}=\beta Y_{i t-1}+\sum_{j=1}^{\eta i} \beta_{i j} Y_{i t-j}+z^{\prime}{ }_{i t} \rho+\mu_{i t}
$$

In the second step, the standard deviation ratio is estimated from the short run to the long run. The null hypothesis is expressed as follows:

$$
\text { NullHypothesis } H_{0}: \rho_{\mathrm{i}}=0
$$

The alternative hypothesis is expressed as follows:

$$
\text { AlternativeHypothesis } H_{1}: \rho_{\mathrm{i}}<0
$$

Equation (5) runs a separate regression and saves the residuals $\rho_{i, t}$ and $\mu_{i, t-1}$ :

$$
\begin{gathered}
\Delta y_{i t}=\lambda \mathbf{i}+\sum_{j=1}^{\eta i} \alpha_{i, t-j} \Delta y_{i, t-j}+\rho_{i, t} \\
y_{i, t-1}=\alpha_{i}-\sum_{j=1}^{\eta i} \phi_{i, t-j} \Delta y_{i, t-j}+\mu_{i, t-1}
\end{gathered}
$$

ADF statistics, as shown in Equation (5), indicate the LLC unit root test, and when based on the unit root presence in the case of $H_{0}$, no unit root problem exists in the alternate hypothesis $H_{1}$. Finally, test statistics are computed and the pooled regression is calculated according to Equation (7):

$$
\Delta y_{i, t}=\lambda y_{i, t-1}+\varepsilon_{i, t}
$$

\subsubsection{IPS Unit Root Test}

The LLC test is restricted because it must be homogeneous, but Pesaran allowed for heterogeneity and proposed an alternative testing procedure that depends on average individual unit root test statistics. The ADF test applied for individual series and t-test statistics depends upon anathematized means of each individual's ADF statistics. It is expressed as the following Equation (8):

$$
\Delta y_{i t}=\alpha_{j}+\alpha_{i} Y_{i t-1}+\sum_{j=1}^{\rho i} \Phi_{i, j} Y_{i t-j}+v_{i, t}
$$

where $\alpha_{i}$ is under the alternative hypothesis and IPS allows heterogeneity. It is more effective than a test for a single time series. It contains two stages; the initial stage shows that the t-statistics of the ADF mean value is calculated for each individual, which is represented in Equation (9):

$$
t_{y z}=\frac{1}{y} \sum_{i=1}^{y} t_{i, t}\left(p_{i}\right)
$$


As $t_{i, t}$ expresses the ADF t-statistics of each country and $p_{i}$ is the lag order in ADF regression; $\mathrm{t}$-statistics are estimated as follows in Equation (10):

$$
A_{t}=\frac{\sqrt{y(z)}\left[\bar{t}_{z}-E\left(t_{z}\right)\right]}{\sqrt{\operatorname{var}\left(t_{z}\right)}}
$$

\subsubsection{Augmented Dickey Fuller (ADF) Unit Root Test}

Maddala and $\mathrm{Wu}$ [56] developed a Fisher type test, which pools the probability values derived from the unit root tests of each cross-section $i$. It has a chi-square distribution with a $2^{\text {nd }}$ degree of freedom and a parametric test, where $\mathrm{n}$ is the number of countries included in the panel. This test is more efficient than the IPS unit root test because it is sensitive to the chosen lag length in individual ADF regressions.

\subsection{Penal Cointegration Tests}

When all variables are integrated at the $1^{\text {st }}$ level, then we move to the next step that is the cointegration test, which is used to predict the presence of long-run relationships among variables. Several tests proposed to investigate whether a long-run relationship existed or not, such as Pedroni [57,58], Kao [59], and Fisher type tests used with an underlying Johansen methodology. In this study, we utilized Kao and Fisher cointegration tests to confirm the cointegration. These tests are based on estimated residuals dynamics of Models A, B and C. Kao and Pedroni cointegration tests are based on the Engle-Granger two-step test (residual-based). The Kao test is used for cross-section and homogeneous coefficients for the first stage. These tests are based on residuals dynamics and variants of ADF and Phillip Perron PP tests. A Fisher panel cointegration test is used to evaluate the null hypothesis $\left(H_{0}\right)$ of "no cointegration" against the alternate hypothesis in the presence of cointegration. Therefore, this study moves toward a penal long-run relationship by applying fully modified OLS (FMOLS) and Dynamic OLS.

\section{Panel Cointegration Regression}

After confirming the long-run cointegration, the next step of the econometric procedure is to estimate the magnitude of the long-run coefficient of variables. In these circumstances, in order to overcome the problem of autocorrelation and endogeneity, we employed FMOLS and DOLS estimation approaches [60,61]. More specifically, the FMOLS approach is considered a non-parametric approach while DOLS is a parametric approach. To overcome the problem faced due to the long-run correlation among the cointegration equation and stochastic regressors' innovations, an econometric technique proposed by Phillips and Hansen was used. Another advantage of FMOLS is to provide consistent and efficient estimators even in data with a small sample size. The results of the FMOLS technique are unbiased and also fully efficient and consistent. This estimator utilized preliminary estimates of the symmetric and one-sided long-run covariance matrices of the residual. This test overcomes the problems of endogeneity and serial correlation.

\subsection{Dumitrescu Hurlin Causality Test}

The Dumitrescu and Hurlin (DH) [62] causality test presented the casual relationship among panel variables. This test gives more useful information than other causality tests. The DH causality test is more appropriate for analyzing unbalanced panel data and cross-sectional dependencies among countries. We considered Equation (11) as a linear model:

$$
\Delta Y_{i t}=\alpha_{i}+\sum_{j=1}^{j} \lambda_{i}^{(j)} Y_{i, t-j}+\sum_{j=1}^{j} \beta_{i}^{(j)} X_{i, t-j}+\mu_{i t}
$$


In Equation (11), $\mathrm{X}$ and $\mathrm{Y}$ are the variables in which causality will be estimated and $\mathrm{j}$ is the optimum lag interval. This test was used to detect whether $X$ causes $Y$ or not.

\section{Results and Discussion:}

In the first step of the analysis, we applied three unit root tests to check the stationary level of the variables listed in Table 1 . The results indicated that the null hypothesis $H_{0}$ was rejected, as shown in Tables 2 and 3 . If all variables are significant at the $1^{\text {st }}$ difference, According to the results of these tests, we have to move toward Cointegration.

Table 2. Results of unit root tests (Western Asia).

\begin{tabular}{|c|c|c|c|c|c|c|c|}
\hline \multirow{2}{*}{ Variables } & \multirow{2}{*}{ Deterministic } & \multicolumn{3}{|c|}{ Level } & \multicolumn{3}{|c|}{$1^{\text {st }}$ difference } \\
\hline & & IPS & LLC & ADF & IPS & LLC & ADF \\
\hline \multirow{2}{*}{ LFDI } & Intercept & $\begin{array}{c}0.498 \\
(0.690)\end{array}$ & $\begin{array}{l}-1.504^{*} \\
(0.080)\end{array}$ & $\begin{array}{l}20.207 \\
(0.684)\end{array}$ & $\begin{array}{c}-11.48^{* * *} \\
(0.000)\end{array}$ & $\begin{array}{c}-8.962 * * * \\
(0.000)\end{array}$ & $\begin{array}{c}164.21^{* * *} \\
0.000\end{array}$ \\
\hline & $\begin{array}{l}\text { Intercept and } \\
\text { trend }\end{array}$ & $\begin{array}{l}-0.113 \\
(0.454)\end{array}$ & $\begin{array}{c}0.561 \\
(0.712)\end{array}$ & $\begin{array}{l}24.261 \\
(0.446)\end{array}$ & $\begin{array}{c}-10.006^{* * * *} \\
(0.000)\end{array}$ & $\begin{array}{c}-6.694^{* * *} \\
(0.000)\end{array}$ & $\begin{array}{c}131.578^{* * *} \\
(0.000)\end{array}$ \\
\hline \multirow{2}{*}{ LGDPPC } & Intercept & $\begin{array}{l}-0.8206 \\
(0.205)\end{array}$ & $\begin{array}{c}-2.394^{* * *} \\
(0.008)\end{array}$ & $\begin{array}{l}31.598 \\
(0.137)\end{array}$ & $\begin{array}{l}-7.285^{* * *} \\
(0.000)\end{array}$ & $\begin{array}{l}-5.884^{* * *} \\
(0.000)\end{array}$ & $\begin{array}{c}101.38^{* * *} \\
(0.000)\end{array}$ \\
\hline & $\begin{array}{l}\text { Intercept and } \\
\text { trend }\end{array}$ & $\begin{array}{l}-1.382 * \\
(0.083)\end{array}$ & $\begin{array}{l}-2.665^{* * *} \\
(0.003)\end{array}$ & $\begin{array}{l}35.567 * \\
(0.060)\end{array}$ & $\begin{array}{c}-5.951^{* * *} \\
(0.000)\end{array}$ & $\begin{array}{c}-5.277^{* * *} \\
(0.000)\end{array}$ & $\begin{array}{c}80.447^{* * *} \\
(0.000)\end{array}$ \\
\hline \multirow{2}{*}{ LLFP } & Intercept & $\begin{array}{c}1.492 \\
(0.932)\end{array}$ & $\begin{array}{l}-0.307 \\
(0.307)\end{array}$ & $\begin{array}{l}12.845 \\
(0.968)\end{array}$ & $\begin{array}{c}-4.886^{* * *} \\
(0.000)\end{array}$ & $\begin{array}{c}-2.806^{* * *} \\
(0.002)\end{array}$ & $\begin{array}{c}67.824^{* * *} \\
(0.000)\end{array}$ \\
\hline & $\begin{array}{l}\text { Intercept and } \\
\text { trend }\end{array}$ & $\begin{array}{c}1.103 \\
(0.865)\end{array}$ & $\begin{array}{c}0.921 \\
(0.178)\end{array}$ & $\begin{array}{l}17.881 \\
(0.808)\end{array}$ & $\begin{array}{c}-3.285^{* * *} \\
(0.000)\end{array}$ & $\begin{array}{c}-3.403^{* * *} \\
(0.000)\end{array}$ & $\begin{array}{l}50.06^{* * *} \\
(0.001)\end{array}$ \\
\hline \multirow{2}{*}{ LTPOP } & Intercept & $\begin{array}{l}0.165 \\
0.565\end{array}$ & $\begin{array}{c}-3.802 * * * \\
0.000\end{array}$ & $\begin{array}{c}52.046^{* * *} \\
(0.000)\end{array}$ & $\begin{array}{c}-12.373^{* * *} \\
(0.000)\end{array}$ & $\begin{array}{c}-11.095^{* * *} \\
(0.000)\end{array}$ & $\begin{array}{c}178.406^{* * *} \\
(0.000)\end{array}$ \\
\hline & $\begin{array}{l}\text { Intercept and } \\
\text { trend }\end{array}$ & $\begin{array}{c}-12.213^{* * *} \\
(0.000)\end{array}$ & $\begin{array}{c}-12.619 * * * \\
(0.000)\end{array}$ & $\begin{array}{c}331.25^{* * *} \\
(0.000)\end{array}$ & $\begin{array}{c}-19.730 * * * \\
(0.000)\end{array}$ & $\begin{array}{c}-17.352 * * * \\
(0.000)\end{array}$ & $\begin{array}{c}426.015^{* * *} \\
(0.000)\end{array}$ \\
\hline \multirow{2}{*}{ LHC } & Intercept & $\begin{array}{c}1.881 \\
(0.970)\end{array}$ & $\begin{array}{l}0.5504 \\
(0.709)\end{array}$ & $\begin{array}{c}13.24 \\
(0.961)\end{array}$ & $\begin{array}{c}-8.906^{* * *} \\
(0.000)\end{array}$ & $\begin{array}{c}-8.805^{* * *} \\
(0.000)\end{array}$ & $\begin{array}{c}123.900 * * * \\
(0.000)\end{array}$ \\
\hline & $\begin{array}{l}\text { Intercept and } \\
\text { trend }\end{array}$ & $\begin{array}{l}-0.387 \\
(0.349)\end{array}$ & $\begin{array}{c}1.225 \\
(0.889)\end{array}$ & $\begin{array}{l}34.016^{*} \\
(0.084)\end{array}$ & $\begin{array}{c}-6.948^{* * *} \\
(0.000)\end{array}$ & $\begin{array}{c}-7.132 * * * \\
(0.000)\end{array}$ & $\begin{array}{l}91.89^{* * *} \\
(0.000)\end{array}$ \\
\hline \multirow{2}{*}{ LUPOP } & Intercept & $\begin{array}{c}0.246 \\
(0.597)\end{array}$ & $\begin{array}{l}-0.273 \\
(0.392)\end{array}$ & $\begin{array}{l}28.345 \\
(0.245)\end{array}$ & $\begin{array}{c}-4.232 * * * \\
(0.000)\end{array}$ & $\begin{array}{c}-4.261 * * * \\
(0.000)\end{array}$ & $\begin{array}{c}62.372 * * * \\
(0.000)\end{array}$ \\
\hline & $\begin{array}{l}\text { Intercept and } \\
\text { trend }\end{array}$ & $\begin{array}{l}-4.544^{* * *} \\
(0.000)\end{array}$ & $\begin{array}{c}-4.737^{* * *} \\
(0.000)\end{array}$ & $\begin{array}{c}61.718^{* * *} \\
(0.000)\end{array}$ & $\begin{array}{c}-4.675^{* * *} \\
(0.000)\end{array}$ & $\begin{array}{c}-4.449^{* * *} \\
(0.000)\end{array}$ & $\begin{array}{c}263.65^{* * *} \\
(0.000)\end{array}$ \\
\hline \multirow{2}{*}{ LTO } & Intercept & $\begin{array}{l}-0.515 \\
(0.303)\end{array}$ & $\begin{array}{c}-2.907^{* * *} \\
(0.001)\end{array}$ & $\begin{array}{l}24.376 \\
(0.440)\end{array}$ & $\begin{array}{l}-9.96^{* * *} \\
(0.000)\end{array}$ & $\begin{array}{c}-7.291 * * * \\
(0.000)\end{array}$ & $\begin{array}{c}140.05^{* * *} \\
(0.000)\end{array}$ \\
\hline & $\begin{array}{l}\text { Intercept and } \\
\text { trend }\end{array}$ & $\begin{array}{c}0.063 \\
(0.525)\end{array}$ & $\begin{array}{c}0.345 \\
(0.635)\end{array}$ & $\begin{array}{l}23.620 \\
(0.483)\end{array}$ & $\begin{array}{c}-8.103^{* * *} \\
(0.000)\end{array}$ & $\begin{array}{c}-5.086^{* * *} \\
(0.000)\end{array}$ & $\begin{array}{c}106.98^{* * *} \\
(0.000)\end{array}$ \\
\hline
\end{tabular}

$1 \%$ and $10 \%$ represented as $* * *$ and $*$ and $p$-values are in parentheses. IPS: Im Pesaran and Shin; LLC: Levin, Lin and $\mathrm{Chu}$; ADF: Augmented Dickey Fuller.

In the second step, Johansen Fisher and Kao panel cointegration tests have been applied to confirm the existence of cointegration among series. Table 4 shows the results of the Kao test while Table 5 and Equation (1), Table 6 and Equation (2), and Table 7 and Equation (3) present the findings of the Johansen Fisher panel co-integration. Fisher cointegration rank 3 was used for western Asia and rank 5 was used for south Asia for the analysis of Equation (2). Max-Eigen test and Trace test values are significant at $1 \%, 5 \%$, and $10 \%$ in both models. These results suggested that the null hypothesis $\left(H_{0}\right)$ of the absence of cointegration is rejected, and confirm that a long-run relationship exists in all models. 
Table 3. Results of unit root tests (Southern Asia).

\begin{tabular}{|c|c|c|c|c|c|c|c|}
\hline \multirow{2}{*}{ Variables } & \multirow{2}{*}{ Deterministic } & \multicolumn{3}{|c|}{ Level } & \multicolumn{3}{|c|}{$1^{\text {st }}$ difference } \\
\hline & & IPS & LLC & ADF & IPS & LLC & $\mathrm{ADF}$ \\
\hline \multirow{2}{*}{ LFDI } & Intercept & $\begin{array}{c}0.756 \\
(0.775)\end{array}$ & $\begin{array}{l}-1.022 \\
(0.153)\end{array}$ & $\begin{array}{c}6.798 \\
(0.942)\end{array}$ & $\begin{array}{c}-10.767^{* * *} \\
(0.000)\end{array}$ & $\begin{array}{l}-5.573^{* * *} \\
(0.000)\end{array}$ & $\begin{array}{c}120.95^{* * *} \\
(0.000)\end{array}$ \\
\hline & $\begin{array}{l}\text { Intercept and } \\
\text { trend }\end{array}$ & $\begin{array}{l}-1.920 \\
(0.027)\end{array}$ & $\begin{array}{l}-0.717 \\
(0.236)\end{array}$ & $\begin{array}{c}25.455^{* *} \\
(0.030)\end{array}$ & $\begin{array}{c}-9.288^{* * *} \\
(0.000)\end{array}$ & $\begin{array}{c}-2.980^{* * *} \\
(0.001)\end{array}$ & $\begin{array}{c}95.535 * * * \\
(0.000)\end{array}$ \\
\hline \multirow{2}{*}{ LGDPPC } & Intercept & $\begin{array}{c}7.302 \\
(1.000)\end{array}$ & $\begin{array}{c}5.169 \\
(1.000)\end{array}$ & $\begin{array}{c}0.943 \\
(1.000)\end{array}$ & $\begin{array}{c}-6.014 * * * \\
(0.000)\end{array}$ & $\begin{array}{c}-4.011 * * * \\
(0.000)\end{array}$ & $\begin{array}{c}67.409 * * * \\
(0.000)\end{array}$ \\
\hline & $\begin{array}{l}\text { Intercept and } \\
\text { trend }\end{array}$ & $\begin{array}{c}0.851 \\
(0.802)\end{array}$ & $\begin{array}{l}-0.578 \\
(0.281)\end{array}$ & $\begin{array}{l}12.365 \\
(0.577)\end{array}$ & $\begin{array}{c}-6.187^{* * *} \\
(0.000)\end{array}$ & $\begin{array}{c}-4.223 * * * \\
(0.000)\end{array}$ & $\begin{array}{c}63.514^{* * *} \\
(0.000)\end{array}$ \\
\hline \multirow{2}{*}{ LLFP } & Intercept & $\begin{array}{c}-0.9455 \\
(0.172)\end{array}$ & $\begin{array}{l}-1.587^{*} \\
(0.056)\end{array}$ & $\begin{array}{l}19.288 \\
(0.154)\end{array}$ & $\begin{array}{c}-3.685^{* * *} \\
(0.000)\end{array}$ & $\begin{array}{l}-2.535^{*} \\
(0.056)\end{array}$ & $\begin{array}{c}42.899 * * * \\
(0.000)\end{array}$ \\
\hline & $\begin{array}{l}\text { Intercept and } \\
\text { trend }\end{array}$ & $\begin{array}{l}-1.165 \\
(0.121)\end{array}$ & $\begin{array}{l}-1.710 \\
(0.043)\end{array}$ & $\begin{array}{l}18.870 \\
(0.170)\end{array}$ & $\begin{array}{c}-2.526^{* * *} \\
(0.005)\end{array}$ & $\begin{array}{l}-2.815^{*} \\
(0.002)\end{array}$ & $\begin{array}{c}32.309^{* * *} \\
(0.003)\end{array}$ \\
\hline \multirow{2}{*}{ LTPOP } & Intercept & $\begin{array}{c}2.703 \\
(0.996)\end{array}$ & $\begin{array}{l}-0.402 \\
(0.343)\end{array}$ & $\begin{array}{l}10.204 \\
(0.747)\end{array}$ & $\begin{array}{c}-5.821^{* * *} \\
(0.000)\end{array}$ & $\begin{array}{c}-3.133^{* * *} \\
(0.000)\end{array}$ & $\begin{array}{c}68.404^{* * *} \\
(0.000)\end{array}$ \\
\hline & $\begin{array}{l}\text { Intercept and } \\
\text { trend }\end{array}$ & $\begin{array}{c}-5.042 * * * \\
(0.000)\end{array}$ & $\begin{array}{c}-4.523 * * * \\
(0.000)\end{array}$ & $\begin{array}{c}59.487^{* * *} \\
(0.000)\end{array}$ & $\begin{array}{l}11.68^{* * * *} \\
(0.000)\end{array}$ & $\begin{array}{l}11.74^{* * * *} \\
(0.000)\end{array}$ & $\begin{array}{c}142.107^{* * *} \\
(0.000)\end{array}$ \\
\hline \multirow{2}{*}{ LHC } & Intercept & $\begin{array}{c}4.559 \\
(1.000)\end{array}$ & $\begin{array}{c}2.275 \\
(0.988)\end{array}$ & $\begin{array}{l}0.958 \\
(1.000)\end{array}$ & $\begin{array}{c}-4.967^{* * *} \\
(0.000)\end{array}$ & $\begin{array}{c}-4.567^{* * *} \\
(0.000)\end{array}$ & $\begin{array}{c}50.702 * * * \\
(0.000)\end{array}$ \\
\hline & $\begin{array}{l}\text { Intercept and } \\
\text { trend }\end{array}$ & $\begin{array}{c}0.173 \\
(0.568)\end{array}$ & $\begin{array}{l}-0.970 \\
(0.165)\end{array}$ & $\begin{array}{c}9.803 \\
(0.776)\end{array}$ & $\begin{array}{c}-3.520 * * * \\
(0.000)\end{array}$ & $\begin{array}{c}-3.273^{* * *} \\
(0.000)\end{array}$ & $\begin{array}{c}35.497^{* * *} \\
(0.001)\end{array}$ \\
\hline \multirow{2}{*}{ LUPOP } & Intercept & $\begin{array}{l}1.653 \\
0.950\end{array}$ & $\begin{array}{l}-0.579 \\
(0.281)\end{array}$ & $\begin{array}{l}11.582 \\
(0.639)\end{array}$ & $\begin{array}{c}-2.652 * * * \\
(0.000)\end{array}$ & $\begin{array}{c}-2.769^{* * *} \\
(0.000)\end{array}$ & $\begin{array}{l}43.95^{* * *} \\
(0.005)\end{array}$ \\
\hline & $\begin{array}{l}\text { Intercept and } \\
\text { trend }\end{array}$ & $\begin{array}{c}0.634 \\
(0.402)\end{array}$ & $\begin{array}{l}-1.605^{*} \\
(0.054)\end{array}$ & $\begin{array}{l}14.611 \\
(0.405)\end{array}$ & $\begin{array}{c}-3.598^{* * *} \\
(0.000)\end{array}$ & $\begin{array}{c}-2.798^{* * *} \\
(0.006)\end{array}$ & $\begin{array}{c}54.676^{* *} \\
(0.000)\end{array}$ \\
\hline \multirow{2}{*}{ LTO } & Intercept & $\begin{array}{l}1.270 \\
(0.898)\end{array}$ & $\begin{array}{l}-0.918 \\
(0.179)\end{array}$ & $\begin{array}{c}5.885 \\
(0.969)\end{array}$ & $\begin{array}{c}-6.996^{* * *} \\
(0.000)\end{array}$ & $\begin{array}{c}-1.584^{* * *} \\
(0.056)\end{array}$ & $\begin{array}{c}74.493 \text { *** } \\
(0.000)\end{array}$ \\
\hline & $\begin{array}{l}\text { Intercept and } \\
\text { trend }\end{array}$ & $\begin{array}{l}0.5163 \\
(0.697)\end{array}$ & $\begin{array}{l}1.723 \\
(0.957)\end{array}$ & $\begin{array}{c}8.243 \\
(0.876)\end{array}$ & $\begin{array}{c}-5.454 * * * \\
(0.000)\end{array}$ & $\begin{array}{c}-6.358^{* * *} \\
(0.000)\end{array}$ & $\begin{array}{c}54.929 * * * \\
(0.000)\end{array}$ \\
\hline
\end{tabular}

$1 \%$ and $10 \%$ represented as ${ }^{* * *}$ and ${ }^{*}$ and $p$-value is in parenthesis.

Table 4. Results of Kao cointegration test.

\begin{tabular}{ccccc}
\hline & & Model A & Model B & Model C \\
\hline \multirow{2}{*}{ Western Asia } & \multirow{2}{*}{ ADF statistics } & $-1.382^{*}$ & $-1.814^{* *}$ & -3.862 \\
& & $(0.083)$ & $(0.034)$ & $(0.000)$ \\
\hline \multirow{2}{*}{ Southern Asia } & \multirow{2}{*}{ ADF statistics } & $-2.411^{* * *}$ & $-1.633^{*}$ & -3.963 \\
& & $(0.007)$ & $(0.051)$ & $(0.000)$ \\
\hline
\end{tabular}

$* * *, * *$, and ${ }^{*}$ significance levels represented as $1 \%, 5 \%$, and $10 \%$, respectively, and $p$-value is in parenthesis

Table 5. Results of Johansen Fisher test for model A.

\begin{tabular}{llllll}
\hline & No. of CE(s) & Trace Test Value & $p$-Value & Max-Eigen Test Value & $p$-Value \\
\hline \multirow{3}{*}{ Western Asia } & None & $169.6^{* * *}$ & 0.000 & $135.6^{* * *}$ & 0.000 \\
\cline { 2 - 6 } & At most 1 & $88.39^{* * *}$ & 0.000 & $64.85^{* * *}$ & 0.000 \\
\cline { 2 - 6 } & At most 2 & $46.77^{* * *}$ & 0.003 & $40.47^{* *}$ & 0.019 \\
\cline { 2 - 6 } Southern Asia & At most 3 & $38.87^{* * *}$ & 0.028 & $38.87^{* *}$ & 0.028 \\
\cline { 2 - 6 } & None & $92.59^{* * *}$ & 0.000 & $56.758^{* * *}$ & 0.000 \\
\cline { 2 - 6 } & At most 1 & $49.12^{* * *}$ & 0.000 & $30.49^{* * *}$ & 0.006 \\
\cline { 2 - 6 } & At most 2 & $32.27^{* * *}$ & 0.003 & $22.68^{*}$ & 0.065 \\
\hline
\end{tabular}

\footnotetext{
$* * *, * *$ and ${ }^{*}$ significance levels are $1 \%, 5 \%$ and $10 \%$.
} 
Table 6. Results of Johansen Fisher test for model B.

\begin{tabular}{llllll}
\hline & No. of CE(s) & Trace test Value & $p$-Value & Max-Eigen test Value & $p$-Value \\
\hline \multirow{4}{*}{ Western Asia } & None & $357.5^{* * *}$ & 0.000 & $247.1^{* * *}$ & 0.000 \\
\cline { 2 - 5 } & At most 1 & $166.4^{* * *}$ & 0.000 & $116.1^{* * *}$ & 0.000 \\
\cline { 2 - 5 } & At most 2 & $73.42^{* *}$ & 0.000 & $61.98^{* * *}$ & 0.000 \\
\cline { 2 - 5 } & At most 3 & $34.33^{*}$ & 0.078 & 28.50 & 0.239 \\
\cline { 2 - 5 } Southern Asia & At most 4 & $35.50^{*}$ & 0.061 & $35.50^{*}$ & 0.061 \\
\hline & None & $247.7^{* * *}$ & 0.000 & $405.2^{* * *}$ & 0.000 \\
\cline { 2 - 5 } & At most 1 & $83.90^{* * *}$ & 0.000 & $50.86^{* * *}$ & 0.000 \\
\cline { 2 - 5 } & At most 2 & $43.27^{* * *}$ & 0.000 & $34.40^{* * *}$ & 0.001 \\
\cline { 2 - 5 } & At most 3 & $20.57^{* *}$ & 0.113 & 14.65 & 0.402 \\
\cline { 2 - 5 } & At most 4 & $28.39^{* *}$ & 0.012 & $28.39^{* *}$ & 0.012 \\
\hline
\end{tabular}

$* * * * *$, and ${ }^{*}$ significance levels are $1 \%, 5 \%$, and $10 \%$, respectively.

Table 7. Results of Johansen Fisher test for model C.

\begin{tabular}{llllll}
\hline & No. of CE(s) & Trace Test Value & $p$-Value & Max-Eigen Test Value & $p$-Value \\
\hline \multirow{3}{*}{ Western Asia } & None & $346.4^{* * *}$ & 0.000 & $235.6^{* * *}$ & 0.000 \\
\cline { 2 - 5 } & At most 1 & $157.0^{* * *}$ & 0.000 & $106.0^{* * *}$ & 0.000 \\
\cline { 2 - 5 } & At most 2 & $78.69^{* *}$ & 0.000 & $53.65^{* * *}$ & 0.000 \\
\cline { 2 - 5 } & At most 3 & $45.27^{* * *}$ & 0.005 & $36.98^{* *}$ & 0.044 \\
\cline { 2 - 5 } Southern Asia & At most 4 & $38.68^{* *}$ & 0.029 & $38.68^{* *}$ & 0.029 \\
\hline & None & $207.8^{* * *}$ & 0.000 & $152.2^{* * *}$ & 0.000 \\
\cline { 2 - 5 } & At most 1 & $89.65^{* * *}$ & 0.000 & $53.43^{* * *}$ & 0.000 \\
\cline { 2 - 5 } & At most 2 & $48.41^{* * *}$ & 0.000 & $30.41^{* * *}$ & 0.007 \\
\cline { 2 - 5 } & At most 3 & $31.19^{* * *}$ & 0.005 & $23.50^{*}$ & 0.052 \\
\cline { 2 - 5 } & At most 4 & $27.51^{* *}$ & 0.016 & $27.51^{* *}$ & 0.016 \\
\hline
\end{tabular}

$* * *, * *$ and ${ }^{*}$ significance levels are $1 \%, 5 \%$, and $10 \%$, respectively.

Table 8 shows the result of Equation (1) by utilizing the FMOLS and DOLS approaches. An increase in human capital raises labor productivity as well as economic growth in both regions. According to the result, in Southern and Western Asia LHC has a significant and positive impact on economic growth. The results of these tests show no difference in term of magnitude and signs averagely. According to the results of FMOLS, a $1 \%$ increase in LHC tends to increase LGDPPC by $0.13 \%$ in Western Asia and $0.38 \%$ in Southern Asia. Furthermore, the results of DOLS indicated that a $1 \%$ increase in LHC tends to increase LGDPPC by $0.14 \%$ in Western Asia and $0.30 \%$ in Southern Asia. There are a few studies that also showed the same relationships $[46,63]$. According to the results of FMOLS, a $1 \%$ increase in LUPOP tends to increase LGDPPC by $0.79 \%$ in Western Asia and $0.66 \%$ in Southern Asia. Furthermore, the results of DOLS indicated that a $1 \%$ increase in LHC tends to increase LGDPPC by $1.27 \%$ in Western Asia and $0.73 \%$ in Southern Asia [64]. Results of FMOLS indicate that LLFP has a significant and positive impact on economic growth in Western Asia, while according to DOLS, LLFP has an insignificant but positive impact in Western Asia. Results of FMOLS and DOLS show that a $1 \%$ increase in LLFP decreases LGDPPC by $1.69 \%$ and $1.49 \%$ in Southern Asia. Results indicate that LLFP has a negative and significant impact on LGDPPC according to FMOLS and an insignificant impact according to DOLS, which is supported by $[39,65]$. When the ratio of labor force participation exceeds labor demand, it causes disequilibrium in the labor market. The result is a reduction in the labor wage rate and in living standards, as well as an increase in LFP that also has a negative impact on economic growth. 
Table 8. Results of fully modified ordinary least square (FMOLS) and dynamic ordinary least square (DOLS) Model A (Dependent variable is LGDPPC).

\begin{tabular}{ccccc}
\hline \multirow{2}{*}{ Variables } & \multicolumn{2}{c}{ FMOLS } & \multicolumn{2}{c}{ DOLS } \\
\cline { 2 - 5 } & Western Asia & Southern Asia & Western Asia & Southern Asia \\
\hline \multirow{2}{*}{ LHC } & $0.136^{* * *}$ & $0.387^{* * *}$ & $0.149^{* * *}$ & $0.300^{* * *}$ \\
& {$[13.200]$} & {$[9.825]$} & {$[2.97]$} & {$[6.833]$} \\
& $(0.000)$ & $(0.000)$ & $(0.003)$ & $(0.000)$ \\
\hline \multirow{2}{*}{ LUPOP } & $0.790^{* * *}$ & $0.667^{* * *}$ & $1.274^{* * *}$ & 0.736 \\
& {$[160.66]$} & {$[5.700]$} & {$[2.678]$} & {$[5.445]$} \\
& $(0.000)$ & $(0.000)$ & $(0.009)$ & $(0.000)$ \\
\hline \multirow{2}{*}{ LLFP } & $1.008^{* * *}$ & $-1.696^{* * *}$ & 0.166 & $-1.494^{* * *}$ \\
& {$[96.534]$} & {$[-3.622]$} & {$[0.605]$} & {$[-2.943]$} \\
& $(0.000)$ & $(0.000)$ & $(0.545)$ & $(0.003)$ \\
\hline
\end{tabular}

$1 \%, 5 \%$, and $10 \%$ represented as ${ }^{* * *}, * *$, and $*$, respectively. $p$-value is in () and t-statistics in [].

Table 9 presents the results of Equation (2). LHC in model B shows similar results to model $\mathrm{A}$, having a positive impact on LGDPPC in both regions but an insignificant and positive impact according to the result of FMOLS. A country's labor efficiency, infrastructure, and human capital caused an increase in FDI. Products produced by foreign investors caused a reduction in the imports of the economy. According to FMOLS and DOLS, LFDI has a significant and positive impact in Southern Asia but has a smaller impact of $0.008 \%$ and $0.018 \%$, respectively for FMOLS and DOLS, on LGDPPC. Results of FMOLS and DOLS show that a $1 \%$ increase in LFDI decreases LGDPPC by $0.04 \%$ and $0.03 \%$ in Western Asia so this indicates that LFDI has a negative and significant impact on the LGDPPC in Western Asia. According to FMOLS and DOLS, LTPOP has a significant and negative impact on LGDPPC in both regions but has an insignificant impact in western Asia. A country's export could be increasing because of the low rate of tariffs and other trading barriers. Trading activities of this country increase, which directly affects economic growth. FMOLS results indicate that a $1 \%$ increase in LTO tends to increase LGDPPC by $0.006 \%$ in Western Asia and $0.05 \%$ in Southern Asia, and thus is insignificant in the Western region. Similarly, the DOLS estimation approach indicated that a $1 \%$ increase in LTO tends to increase LGDPPC by $0.39 \%$ in Western Asia and $0.19 \%$ in Southern Asia.

Table 9. Results of FMOLS and DOLS Model B (Dependent variable is LGDPPC).

\begin{tabular}{ccccc}
\hline \multirow{2}{*}{ Variables } & \multicolumn{2}{c}{ FMOLS } & \multicolumn{2}{c}{ DOLS } \\
\cline { 2 - 5 } & Western Asia & Southern Asia & Western Asia & Southern Asia \\
\hline \multirow{3}{*}{ LHC } & 0.165 & $0.042^{*}$ & $0.045^{* *}$ & $0.136^{* * *}$ \\
& {$[1.358]$} & {$[1.734]$} & {$[0.323]$} & {$[9.702]$} \\
& $(0.175)$ & $(0.084)$ & $(0.7464)$ & $(0.000)$ \\
\hline \multirow{2}{*}{ LTO } & 0.066 & $0.052^{*}$ & $0.339 * * *$ & $0.195^{* * *}$ \\
& {$[0.861]$} & {$[1.897]$} & {$[4.447]$} & {$[4.258]$} \\
& $(0.389)$ & $(0.059)$ & $(0.000)$ & $(0.000)$ \\
LFDI & $-0.047^{* * * *}$ & $0.008^{*}$ & $-0.037^{* * *}$ & $0.018^{* *}$ \\
& $(-3.543)$ & {$[1.726]$} & {$[-2.726]$} & {$[2.336]$} \\
& {$[0.000]$} & $(0.085)$ & $(0.007)$ & $(0.021)$ \\
\hline \multirow{2}{*}{ LTPOP } & $-1.129^{* * *}$ & $-0.445^{*}$ & $-2.691 * * *$ & $-1.112^{* *}$ \\
& $(-2.178)$ & {$[-2.034]$} & {$[-4.438]$} & {$[-4.001]$} \\
& {$[0.389]$} & $(0.043)$ & $(0.000)$ & $(0.000)$ \\
\hline
\end{tabular}

$1 \%$. and $5 \%$ levels of significance represented as ${ }^{* * *}$ and $^{* *}$, respectively. $p$-value is in () and t-statistics in [].

Table 10 presents the results of Equation (3). According to FMOLS and DOLS, LHC has a significant but positive impact on LTO in both panels. More specifically, according to the results of FMOLS, a $1 \%$ increase in LHC tends to increase LTO by $0.25 \%$ in Western Asia and $0.09 \%$ in Southern Asia. 
Furthermore, the results of DOLS indicated that a 1\% increase in LHC would lead to an increase of LTO by $0.51 \%$ in Western Asia and $0.28 \%$ in Southern Asia. The results of FMOLS and DOLS show that a $1 \%$ increase in LLFP decreases trade openness by $0.03 \%$ and $0.42 \%$ in Western Asia, respectively, so the result indicates that LLFP has a negative and significant impact on LTO in Western Asia; however according to FMOLS it is insignificant. Furthermore, results indicated that LLFP has a positive and significant impact on LTO in Southern Asia. The results of FMOLS and DOLS show that a 1\% increase in LLFP increases trade openness by $0.33 \%$ and $0.32 \%$, respectively, in Southern Asia. LFDI has a positive and significant impact on trade openness according to FMOLS and DOLS. In Western Asia, LFDI has a smaller but still positive impact on trade openness; the results also indicated that a $1 \%$ increase in LFDI increases trade openness by $0.07 \%$ in Western Asia. The results of FMOLS and DOLS show that a $1 \%$ increase in LFDI increases trade openness by $0.16 \%$ and $0.15 \%$ in Southern Asia, respectively. According to FMOLS and DOLS, LTPOP has a significant and negative impact on LTO in both regions.

Table 10. Results of FMOLS and DOLS Model C (Dependent variable is LTO).

\begin{tabular}{ccccc}
\hline \multirow{2}{*}{ Variables } & \multicolumn{2}{c}{ FMOLS } & \multicolumn{2}{c}{ DOLS } \\
\cline { 2 - 5 } & Western Asia & Southern Asia & Western Asia & Southern Asia \\
\hline \multirow{2}{*}{ LHC } & $0.254^{* * *}$ & $0.098^{* *}$ & $0.517^{* * *}$ & $0.285^{* * *}$ \\
& {$[3.835]$} & {$[1.981]$} & {$[8.679]$} & {$[7.795]$} \\
& $(0.000)$ & $(0.048)$ & $(0.000)$ & $(0.000)$ \\
\hline \multirow{2}{*}{ LLFP } & -0.031 & $0.332^{* * *}$ & $-0.424^{* *}$ & $0.324^{* * *}$ \\
& {$[-0.312]$} & {$[5.758]$} & {$[-2.005]$} & {$[3.623]$} \\
\multirow{2}{*}{ LFDI } & $(0.754)$ & $(0.000)$ & $(0.046)$ & $(0.000)$ \\
& $0.071^{* * *}$ & $0.164^{* * *}$ & $0.079 * * *$ & $0.159^{* * *}$ \\
& $(5.011)$ & {$[9.269]$} & {$[9.017]$} & {$[10.251]$} \\
LTPOP & {$[0.000]$} & $(0.000)$ & $(0.000)$ & $(0.021)$ \\
& $-0.180^{* * *}$ & $-0.331^{* * *}$ & $-0.148^{* * *}$ & $-0.330^{* * *}$ \\
& $(-7.328)$ & {$[-15.295]$} & {$[-2378]$} & {$[-9.890]$} \\
& {$[0.000]$} & $(0.000)$ & $(0.018)$ & $(0.000)$ \\
\hline
\end{tabular}

$1 \%$ and $5 \%$ levels of significance are represented as ${ }^{* * *}$ and ${ }^{* *}$, respectively. $p$-value is in () and t-statistics in [].

Table 11 presents the results of the DH granger causality test [62] of Equation (1). If the $p$-value is significant at $1 \%, 5 \%$, and $10 \%$, we then reject $H_{0}$, meaning that $X$ does not homogeneously cause Y [66]. In Southern Asia's LHC, LGPPC is not significant at any level so we cannot reject the null hypothesis, and in Western Asia it is significant at $1 \%$, so we can reject $H_{0}$. Similarly, for LGDPPC, LHC has a significant value so results supported the rejection of the null hypothesis in Southern Asia, and we cannot reject the null hypothesis in Western Asia, which indicates a unidirectional causality between LHC and LGDPPC. LLFP and LGDPPC have a unidirectional relationship in both regions. LUPOP and LGDPPC and LGDPPC and LUPOP both have values at $1 \%$ and $10 \%$, so we reject the null hypothesis and the results suggested that a bidirectional causality relationship exists between LUPOP and LGDPPC. LHC and LUPOP have a unidirectional causality relationship in Southern Asia and a bidirectional causality relationship in Western Asia. Furthermore, LUPOP and LHC have a bidirectional relationship in both regions; all $p$-values are significant at $1 \%$. The causality relationship flow for model (A) is presented in Figure 2. 
Table 11. Dumitrescu Hurlin causality test Model (A) for Western Asia and Southern Asia.

\begin{tabular}{ccccccc}
\hline \multirow{2}{*}{ Direction of Causality } & \multicolumn{3}{c}{ Western Asia } & \multicolumn{3}{c}{ Southern Asia } \\
\cline { 2 - 7 } & $W_{N, T}^{H N C}$ & $Z_{N, T}^{H N C}$ & $p$-Value & $W_{N, T}^{H N C}$ & $Z_{N, T}^{H N C}$ & $p$-Value \\
\hline LLFP $\rightarrow$ LGDPPC & $3.6617^{* *}$ & $2.1987^{* *}$ & 0.027 & 3.2007 & 1.1615 & 0.2454 \\
LGDPPC $\rightarrow$ LLFP & $2.9004^{* *}$ & 1.0792 & 0.280 & $4.1875^{* *}$ & $2.2700^{* *}$ & 0.023 \\
\hline LHC $\rightarrow$ LGDPPC & $4.9275^{* * *}$ & 4.0603 & 0.000 & 3.0933 & 1.0409 & 0.297 \\
LGDPPC $\rightarrow$ LHC & $2.9118^{*}$ & 1.0959 & 0.273 & $3.9102^{* * *}$ & $4.7069^{* * *}$ & 0.000 \\
\hline LUPOP $\rightarrow$ LGDPPC & $9.7933^{* * *}$ & $11.216^{* * *}$ & 0.000 & $9.2165^{* * *}$ & $7.9189^{* * *}$ & 0.000 \\
LGDPPC $\rightarrow$ LUPOP & $4.2634^{* * *}$ & $3.083^{* * *}$ & 0.002 & $3.7083^{*}$ & $1.7317^{*}$ & 0.083 \\
\hline LHC $\rightarrow$ LLFP & $4.0305^{* * *}$ & $2.7411^{* * *}$ & 0.006 & 2.3492 & $0.2050^{* * *}$ & 0.837 \\
LLFP $\rightarrow$ LHC & $3.3604^{*}$ & $1.7556^{*}$ & 0.079 & $5.2258^{* * *}$ & $3.4362^{* * *}$ & 0.006 \\
\hline LUPOP $\rightarrow$ LLFP & $5.4791^{* * *}$ & $4.8715^{* * *}$ & 0.000 & $4.8247^{* * *}$ & $2.9857^{* * *}$ & 0.002 \\
LLFP $\rightarrow$ LUPOP & $7.5685^{* * *}$ & $7.9445^{* * *}$ & 0.000 & 2.4226 & $0.2875^{* *}$ & 0.773 \\
\hline LUPOP $\rightarrow$ LHC & $6.8998^{* * *}$ & $6.9610^{* * *}$ & 0.000 & $7.5960^{* * *}$ & $6.0986^{* * *}$ & 0.000 \\
LHC $\rightarrow$ LUPOP & $4.6214^{* * *}$ & $3.6102^{* * *}$ & 0.000 & $7.6493^{* * *}$ & $6.1585^{* * *}$ & 0.000
\end{tabular}

$1 \%, 5 \%$, and $10 \%$ represented as ${ }^{* * *}, * *$, and $*$, respectively.

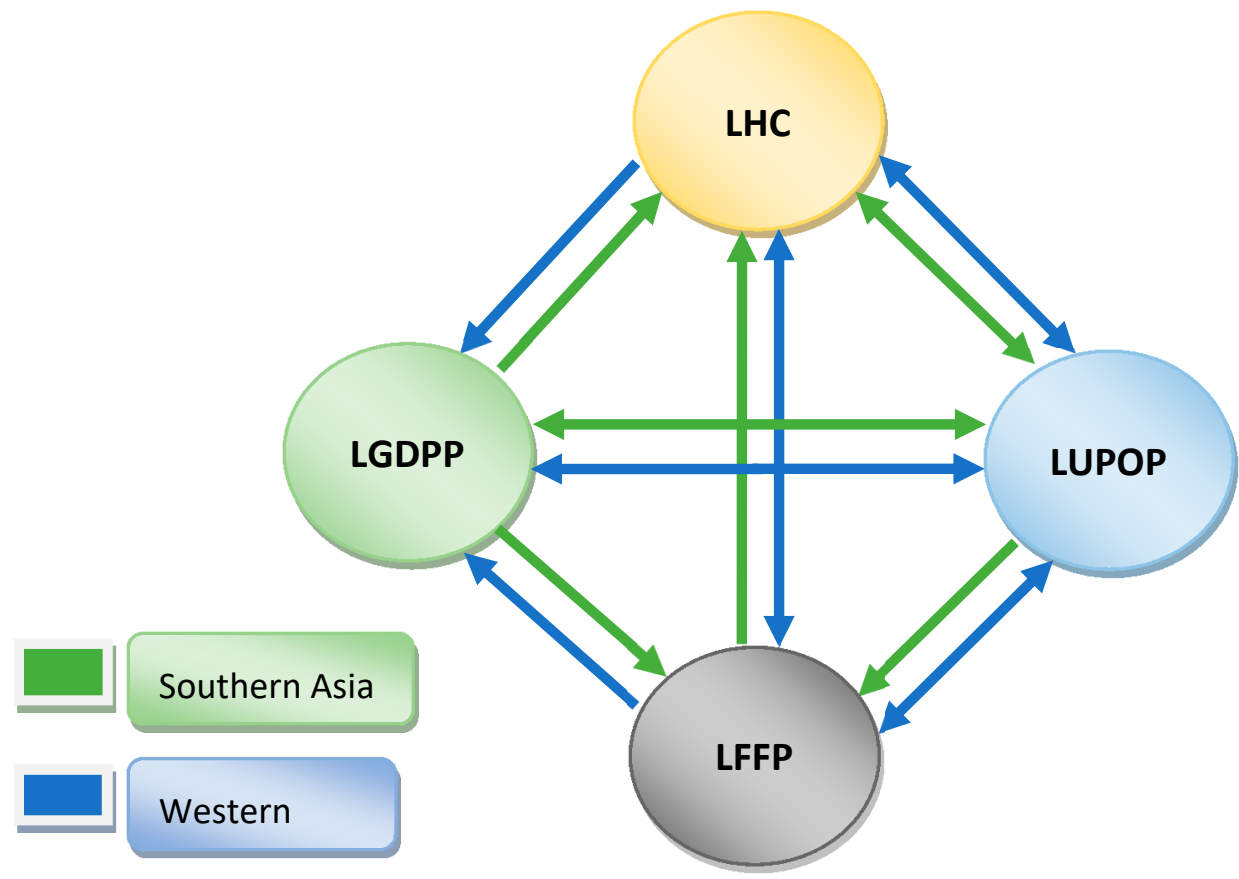

Figure 2. Causality Relationship Flows for Model (A).

Table 12 represents the results of the DH panel granger causality test for Equation (2). The variables LHC and LGDPPC have a unidirectional causal relationship in both regions. Furthermore, LTPOP and LGDPPC as well as LHC and LFDI have a bidirectional relationship in both regions. These results are in line with Abdouli and Omri [67]. LTO and LFDI have a unidirectional causality relationship in western Asia and a bidirectional causality relationship in southern Asia. LTO and LHC also have the same results. Moreover, LTPOP and LFDI have a unidirectional causality relationship in Southern Asia and a bidirectional causal relationship in Western Asia. LTPOP has a bidirectional relationship with LHC and LTO in both regions. The causality relationship flow for model (B) is presented in Figure 3. 
Table 12. Dumitrescu Hurlin causality test from Model B for Western Asia and Southern Asia.

\begin{tabular}{ccccccc}
\hline \multirow{2}{*}{ Direction of Causality } & \multicolumn{3}{c}{ Western Asia } & \multicolumn{3}{c}{ Southern Asia } \\
\cline { 2 - 6 } & $W_{N, T}^{H N C}$ & $Z_{N, T}^{H N C}$ & $p$-Value & $W_{N, T}^{H N C}$ & $Z_{N, T}^{H N C}$ & $p$-Value \\
\hline LFDI $\rightarrow$ LGDPPC & $5.7656^{* * *}$ & $5.2890^{* * *}$ & 0.000 & 1.7389 & -0.48045 & 0.630 \\
LGDPPC $\rightarrow$ LFDI & $4.8009^{* * *}$ & $3.8710^{* * *}$ & 0.000 & $6.3344^{* * *}$ & $4.6815^{* * *}$ & 0.000 \\
\hline LHC $\rightarrow$ LGDPPC & $4.9275^{* * *}$ & $4.0987^{* * *}$ & 0.000 & 3.0933 & 1.0409 & 0.297 \\
LGDPPC $\rightarrow$ LHC & $2.9118^{* * *}$ & $1.0959^{* * *}$ & 0.273 & $6.3571^{* * *}$ & $4.7069^{* * *}$ & 0.000 \\
\hline LTO $\rightarrow$ LGDPPC & $4.6883^{* * *}$ & $3.7086^{* * *}$ & 0.000 & 1.1178 & -1.17807 & 0.238 \\
LGDPPC $\rightarrow$ LTO & $5.1343^{* * *}$ & $4.3644^{* * *}$ & 0.000 & $4.9025^{* * *}$ & $3.0731^{* * *}$ & 0.002 \\
\hline LTPOP $\rightarrow$ LGDPPC & $6.0760^{* * *}$ & $5.7495^{* * *}$ & 0.000 & $5.2741^{* * *}$ & $3.4904^{* * *}$ & 0.000 \\
LGDPPC $\rightarrow$ LTPOP & $8.7503^{* * *}$ & $9.6826^{* * *}$ & 0.000 & $15.512^{* * *}$ & $14.991^{* * *}$ & 0.000 \\
\hline LHC $\rightarrow$ LFDI & $4.6213^{* * *}$ & $3.6070^{* * *}$ & 0.000 & $5.0496^{* * *}$ & $3.2383^{* * *}$ & 0.001 \\
LFDI $\rightarrow$ LHC & $3.7682^{* *}$ & $2.3553^{* *}$ & 0.018 & $3.6420^{*}$ & $1.65729^{*}$ & 0.097 \\
\hline LTO $\rightarrow$ LFDI & $3.1819^{*}$ & 1.4913 & 0.135 & $6.0841^{* * *}$ & $4.4003^{* * *}$ & 0.000 \\
LFDI $\rightarrow$ LTO & $4.9350^{* * *}$ & $4.0681^{* * *}$ & 0.000 & $4.6993^{* * *}$ & $2.8448^{* * *}$ & 0.004 \\
\hline LTPOP $\rightarrow$ LFDI & $5.6734^{* * *}$ & $5.1534^{* * *}$ & 0.000 & $10.691^{* * *}$ & $9.5752^{* * *}$ & 0.000 \\
LFDI $\rightarrow$ LTPOP & $8.9284^{* * *}$ & $9.9378^{* * *}$ & 0.000 & 3.6096 & $1.6208^{*}$ & 0.105 \\
\hline LTO $\rightarrow$ LHC & $2.3833^{* * *}$ & $0.3170^{* * *}$ & 0.751 & $5.9594^{* * *}$ & $4.2602^{* * *}$ & 0.000 \\
LHC $\rightarrow$ LTO & $4.9026^{* * *}$ & 0.000 & $4.7941^{* * *}$ & $2.9513^{* * *}$ & 0.003 \\
\hline LTPOP $\rightarrow$ LHC & $4.9557^{* * *}$ & $4.1018^{* * *}$ & 0.000 & $6.1398^{* * *}$ & $4.4628^{* * *}$ & 0.000 \\
LHC $\rightarrow$ LTPOP & $16.4274^{* * *}$ & $20.973^{* * *}$ & 0.000 & $19.621^{* * *}$ & $19.606^{* * *}$ & 0.000 \\
\hline LTPOP $\rightarrow$ LTO & $4.9747^{* * *}$ & $4.1298^{* * *}$ & 0.000 & $4.8031^{* * *}$ & $2.9614^{* * *}$ & 0.003 \\
LTO $\rightarrow$ LTPOP & $8.2161^{* * *}$ & $8.8969^{* * *}$ & 0.000 & $11.3265^{* * *}$ & $10.288^{* * *}$ & 0.000 \\
\hline
\end{tabular}

$1 \%, 5 \%$, and $10 \%$ represented as ${ }^{* * *}, * *$, and $*$, respectively.

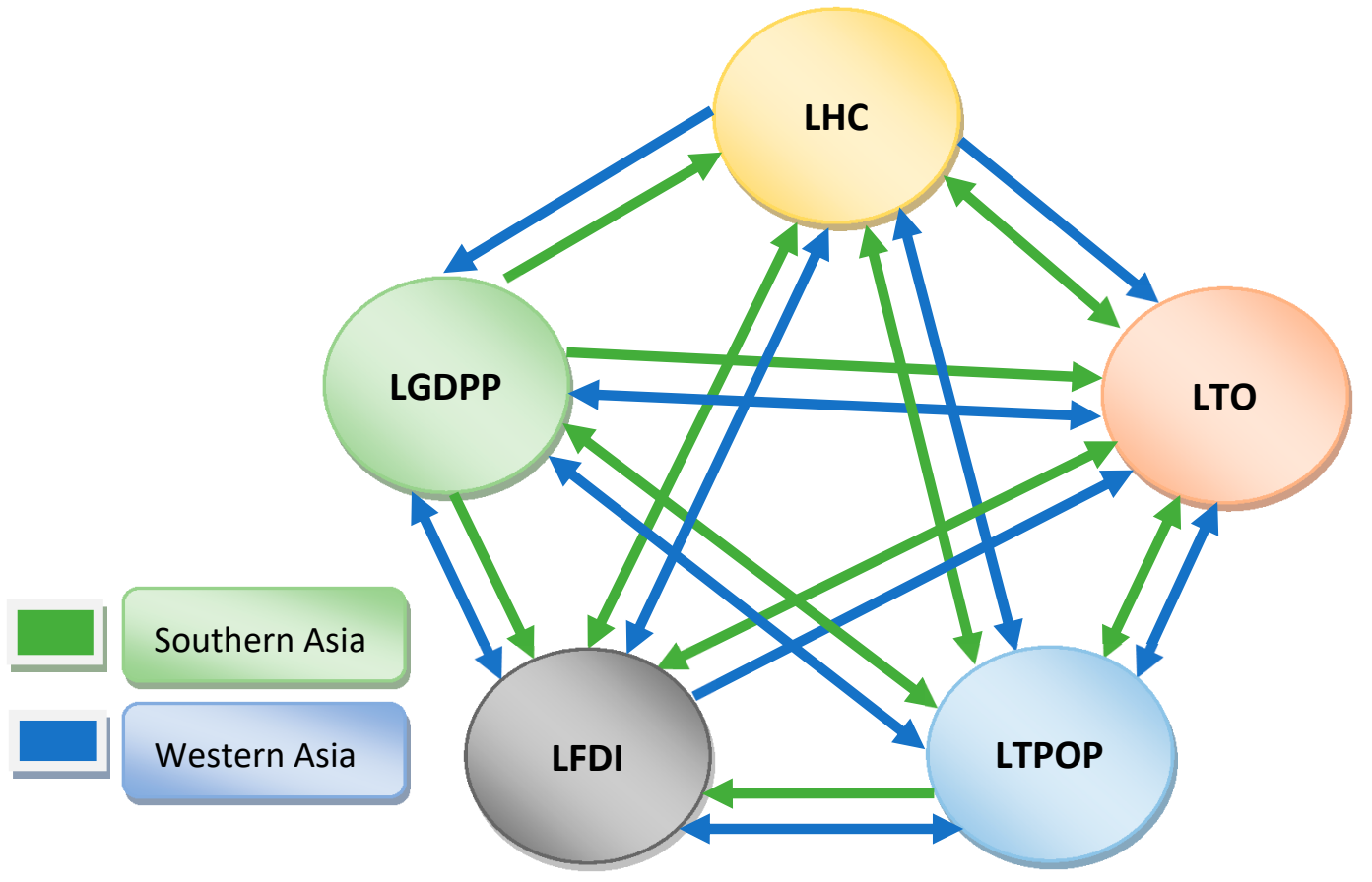

Figure 3. Causality Relationship Flows for Model (B).

Table 13 represents the results of the DH panel granger causality test for Equation (3). LTO has a bidirectional causality relationship with LLFP in both regions, and LTPOP has bidirectional causality relations with LTO, LLFP, and LHC. LTO has bidirectional causality relations with LHC and LFDI in Southern Asia and has a unidirectional causality relationship with Western Asia. LTPOP and LFDI have unidirectional causality in Southern Asia and bidirectional causality in Western Asia. LFDI and 
LLFP have unidirectional causality in both panels. LHC has a bidirectional causality relationship with LLFP in western Asia and a unidirectional causality relationship in the case of Southern Asia. The causality relationship flow for model (C) is expressed in Figure 4.

Table 13. Dumitrescu Hurlin Causality test from Model C for Western Asia and Southern Asia.

\begin{tabular}{|c|c|c|c|c|c|c|}
\hline \multirow{2}{*}{ Direction of Causality } & \multicolumn{3}{|c|}{ Western Asia } & \multicolumn{3}{|c|}{ Southern Asia } \\
\hline & $W_{N, T}^{H N C}$ & $Z_{N, T}^{H N C}$ & $p$-Value & $W_{N, T}^{H N C}$ & $Z_{N, T}^{H N C}$ & $p$-Value \\
\hline LHC $\rightarrow$ LTO & $4.9026^{* * *}$ & $4.0238^{* * *}$ & 0.000 & $4.7941^{* * *}$ & $2.9513^{* * *}$ & 0.003 \\
\hline $\mathrm{LTO} \rightarrow \mathrm{LHC}$ & 2.3822 & 0.3170 & 0.751 & $5.9594^{* * *}$ & $4.2602^{* * *}$ & 0.000 \\
\hline LLFP $\rightarrow$ LTO & $5.2738^{* * *}$ & $4.5696^{* * *}$ & 0.000 & $5.7947 * * *$ & $4.0753 * * *$ & 0.000 \\
\hline LTO $\rightarrow$ LLFP & $3.3710 *$ & $1.7712 *$ & 0.076 & $3.7344 *$ & $1.7610 *$ & 0.078 \\
\hline FDI $\rightarrow$ LTO & $4.9350^{* * *}$ & $4.1298^{* * *}$ & 0.000 & $4.6993 * * *$ & $2.8448^{* * *}$ & 0.004 \\
\hline $\mathrm{LFDI} \rightarrow \mathrm{LTO}$ & 3.1819 & 1.4913 & 0.135 & $6.0841^{* * *}$ & $4.4003^{* * *}$ & 0.000 \\
\hline LTPOP $\rightarrow$ LTO & $4.9747^{* * *}$ & $4.1298^{* * *}$ & 0.000 & $4.8031^{* * *}$ & $2.9614^{* * *}$ & 0.003 \\
\hline LTO $\rightarrow$ LTPOP & $8.2161^{* * *}$ & $8.8969^{* * *}$ & 0.000 & $11.326^{* * *}$ & $10.288^{* * *}$ & 0.000 \\
\hline $\mathrm{LLFP} \rightarrow \mathrm{LHC}$ & $3.3604 *$ & $3.6070 *$ & 0.079 & $5.2258^{* * *}$ & $3.4362 * * *$ & 0.000 \\
\hline LHC $\rightarrow$ LLFP & $4.0305^{* * *}$ & $2.7411^{* * *}$ & 0.006 & 2.3492 & 0.2050 & 0.837 \\
\hline $\mathrm{LFDI} \rightarrow \mathrm{LHC}$ & $3.7682 * *$ & $2.3532 * *$ & 0.018 & $3.6420 *$ & $1.6572 *$ & 0.097 \\
\hline LHC $\rightarrow$ LFDI & $4.6213^{* * *}$ & $3.6070^{* * *}$ & 0.000 & $5.0496 * *$ & $3.2383 * *$ & 0.012 \\
\hline LTPOP $\rightarrow$ LHC & $4.9557^{* * *}$ & $4.1018^{* * *}$ & 0.000 & $6.1398^{* * *}$ & $4.4628^{* * *}$ & 0.000 \\
\hline LHC $\rightarrow$ LTPOP & $16.427^{* * *}$ & $20.973^{* * *}$ & 0.000 & $19.621^{* * *}$ & $19.606^{* * *}$ & 0.000 \\
\hline LFDI $\rightarrow$ LLFP & $5.8985 * * *$ & $5.4843^{* * *}$ & 0.000 & 2.9415 & 0.8703 & 0.384 \\
\hline LLFP $\rightarrow$ LFDI & 3.1764 & 1.4832 & 0.138 & $5.3558^{* * *}$ & $3.5823 * * *$ & 0.000 \\
\hline LTPOP $\rightarrow$ LLFP & $8.5022 * * *$ & $9.3176^{* * *}$ & 0.000 & $6.4772 * * *$ & $4.8419 * * *$ & 0.000 \\
\hline LLFP $\rightarrow$ LTPOP & $17.208^{* * *}$ & $22.121^{* * *}$ & 0.000 & $9.1722 * * *$ & $7.8691^{* * *}$ & 0.000 \\
\hline LTPOP $\rightarrow$ LFDI & $5.6734 * * *$ & $5.1534^{* * *}$ & 0.000 & $10.691^{* * *}$ & $9.5752 * * *$ & 0.003 \\
\hline LFDI $\rightarrow$ LTPOP & $8.9284^{* * *}$ & $9.9378^{* * *}$ & 0.000 & 3.6096 & 1.6208 & 0.105 \\
\hline
\end{tabular}

$1 \%, 5 \%$, and $10 \%$ represented as ${ }^{* * *}, * *$, and ${ }^{*}$, respectively.

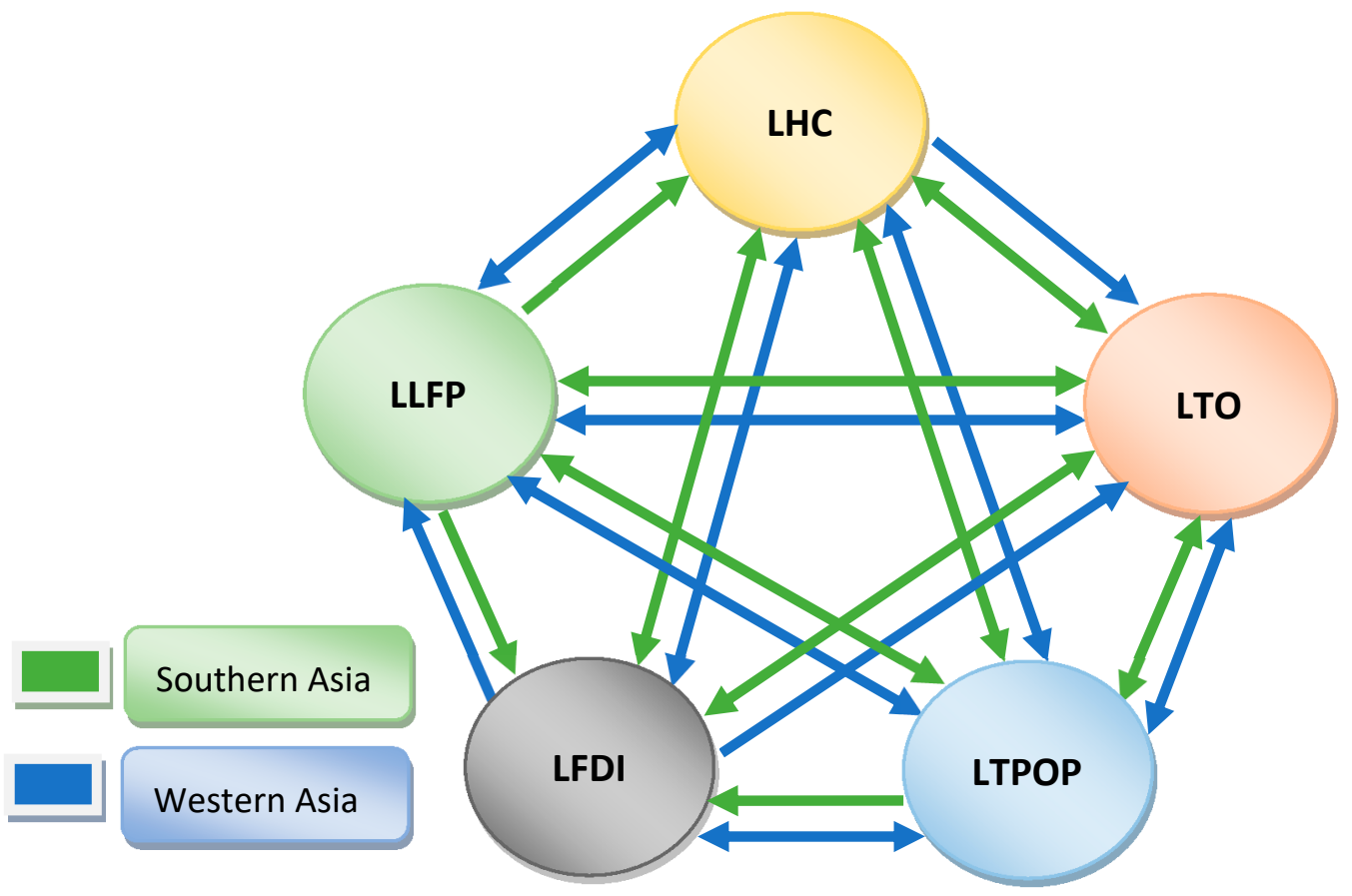

Figure 4. Causality Relationship Flows for Model (C). 


\section{Conclusions and Policy Recommendations}

The main objective of this study was to investigate the impact of trade openness and human capital on economic growth in Asia. We did a compression of Western Asia and Southern Asia on the basis of different GDP per capita in these regions. Here the data are available from 19 countries from 1985 to 2017. We have applied several unit root tests to check the stationarity level and results showed that all variables are integrated at the $1^{\text {st }}$ difference. These results suggested moving toward cointegration tests. Kao and Fisher panel cointegration tests were used to analyze the existence of long-run relationships. After confirming the cointegration among variables, we applied FMOLS and DOLS approaches to find the magnitude of long-run coefficients. The results of this study revealed that trade openness and human capital have a significant and positive relationship with economic growth, while the labor force has a negative impact on the economic growth in Southern Asia and a positive impact on the economic growth in Western Asia. LFDI has a negative and significant impact on LGDPPC in Western Asia and a positive and significant impact in Southern Asia, while LTPOP has a negative impact on LGDPPC in both regions. Furthermore, according to FMOLS and DOLS, LUPOP and other variables also have a significant and positive relationship with LGDPPC in both regions. By utilizing the DH non-causality test we concluded that trade openness and economic growth have bidirectional causality in Western Asia and a unidirectional causal relationship in Southern Asia. It was also revealed that human capital and economic growth have unidirectional causality in both regions. In the trade openness model, we observed that human capital and foreign direct investment accelerated trade openness in both regions, while increasing the total population level reduced the trade level. LLFP reduced the trade openness in Western Asia while it increased the trade level in southern Asia significantly.

This study suggests some policy recommendations on the basis of findings. Due to high population, most of the underdeveloped countries are rich in terms of their labor force. According to the results of this study, policy makers of Southern Asia are required to increase the employment level by creating more job opportunities. It will be helpful to build the equilibrium in the labor market and reduce the negative impact of labor force participation. Human capital is a key factor in economic growth [68]. Human capital consists of knowledge, abilities, and skills that enable people to realize their potential as productive members of society. Improvement in skills and abilities can enhance human capital as well as economic growth, so for this purpose governments should promote education. The policy makers are suggested to invest more in education, special training programs, and technical education to make human capital beneficial for economic output, as the results revealed that a positive relationship between trade openness and economic growth exists. Furthermore, this study suggests that economies should enhance the process of trade openness if they want to develop more rapidly in the long run. The policy makers should promote trade openness by reducing tariff rates and non-tariff taxes on trade. The central authorities of these countries should apply sound foreign and educative policies to attract FDI, as well as create more job opportunities.

Author Contributions: R.A.I.: conceptualization, data curation, formal analysis, writing; M.R.Y.: writing, formal analysis, review and editing; R.K.: methodology, formal analysis, review and editing; M.U.: econometric analysis, review and editing; M.S.A.M.: project administration, conceptualization, econometric analysis, review and editing. All authors have read and agreed to the published version of the manuscript.

Funding: No funding was received for this study.

Acknowledgments: We are grateful to the anonymous reviewers for their positive comments and improvements to the manuscript.

Conflicts of Interest: There is no conflict of interest to the best of our knowledge.

\section{References}

1. Developing Economies: An Empirical Analysis. Eur. Online J. Nat. Soc. Sci. 2019, 8, 411. 
2. Cohen, D.; Soto, M. Growth and human capital: Good data, good results. J. Econ. Growth 2007, 12, 51-76. [CrossRef]

3. Goldberg, P.; Khandelwal, A.; Pavcnik, N.; Topalova, P. Trade liberalization and new imported inputs. Am. Econ. Rev. 2009, 99, 494-500. [CrossRef]

4. Miller, S.M.; Upadhyay, M.P. The effects of openness, trade orientation, and human capital on total factor productivity. J. Dev. Econ. 2000, 63, 399-423. [CrossRef]

5. Sulaiman, C.; Bala, U.; Tijani, B.A.; Waziri, S.I.; Maji, I.K. Human capital, technology, and economic growth: Evidence from Nigeria. SAGE Open 2015, 5, 2158244015615166. [CrossRef]

6. Pernia, E.M.; Quising, P.F. Trade openness and regional development in a developing country. In Globalization and Urban Development; Springer: Berlin/Heidelberg, Germany, 2005; pp. 79-94.

7. Talberth, J.; Bohara, A.K. Economic openness and green GDP. Ecol. Econ. 2006, 58, 743-758. [CrossRef]

8. Nasreen, S.; Anwar, S. Causal relationship between trade openness, economic growth and energy consumption: A panel data analysis of Asian countries. Energy Policy 2014, 69, 82-91. [CrossRef]

9. Adams, S. Foreign direct investment, domestic investment, and economic growth in Sub-Saharan Africa. J. Policy Model. 2009, 31, 939-949. [CrossRef]

10. Najarzadeh, R.; Rahimzadeh, F.; Reed, M. Does the Internet increase labor productivity? Evidence from a cross-country dynamic panel. J. Policy Model. 2014, 36, 986-993. [CrossRef]

11. Johnson, G.E.; Stafford, F.P. International competition and real wages. Am. Econ. Rev. 1993, 83, 127-130.

12. Agbettor, E.O. Human Capital and National Development. In Key Determinants of National Development; Emerald Publishing Limited: Bingley, UK, 2018.

13. Robeyns, I. Three models of education: Rights, capabilities and human capital. Sch. Field 2006, 4, 69-84. [CrossRef]

14. De Oliveira, M.M.; Santos, M.C.; Kiker, B.F. The role of human capital and technological change in over education. Econ. Educ. Rev. 2000, 19, 199-206. [CrossRef]

15. Shutt, J.; Sutherland, J. Encouraging the transition into self-employment. Reg. Stud. 2003, 37, 97-103. [CrossRef]

16. Bottazzi, L.; Da Rin, M.; Hellmann, T.F. Active Financial Intermediation: Evidence on the Role of Organizational Specialization and Human Capital; CEPR: London, UK, 2004.

17. Stiglitz, J.E. Making Natural Resources into a Blessing rather than a Curse. In Covering Oil: A Report. Guide Energy Development; Open Society Institute: New York, NY, USA, 2005.

18. Brown, P. The opportunity trap: Education and employment in a global economy. Eur. Educ. Res. J. 2003, 2, 141-179. [CrossRef]

19. Cleeve, E.A.; Debrah, Y.; Yiheyis, Z. Human capital and FDI inflow: An assessment of the African case. World Dev. 2015, 74, 1-14. [CrossRef]

20. Majeed, M.; Ahmad, E. Human Capital Development and FDI in Developing Countries; Gower Publishing Company Ltd.: Hampshire, UK, 2008.

21. Köhler, J.; Grubb, M.; Popp, D.; Edenhofer, O. The transition to endogenous technical change in climate-economy models: A technical overview to the innovation modeling comparison project. Energy J. 2006, 17-55. [CrossRef]

22. Galor, O. Unified growth theory. Handb. Econ. Growth 2005, 1, 171-293.

23. Galor, O. Unified Growth Theory; Princeton University Press: Princeton, NJ, USA, 2011.

24. Ogundari, K.; Awokuse, T. Human capital contribution to economic growth in Sub-Saharan Africa: Does health status matter more than education? Econ. Anal. Policy 2018, 58, 131-140. [CrossRef]

25. Ahsan, H.; Haque, M.E. Threshold effects of human capital: Schooling and economic growth. Econ. Lett. 2017, 156, 48-52. [CrossRef]

26. Abdullah, A.J. Education and economic growth in Malaysia: The issues of education data. Procedia Econ. Financ. 2013, 7, 65-72. [CrossRef]

27. Pritchett, L. Where Has All the Education Gone? World Bank Econ. Rev. 2001, 15, 367-391. [CrossRef]

28. Awan, A.G.; Naseem, R. The impact of Government Expenditures on Economic Development in Pakistan. Global Journal of Management. Soc. Sci. Humanit. 2018, 5, 562-565.

29. Dar, A.; Muhammad, T.; Mehmood, B. Is There a Relationship between Foreign Direct Investment, Human Capital, Trade Openness and Economic Growth of Pakistani Economy? OECD: Paris, France, 2016. 
30. Sakyi, D.; Villaverde, J.; Maza, A. Trade openness, income levels, and economic growth: The case of developing countries1970-2009. J. Int. Trade Econ. Dev. 2015, 24, 860-882. [CrossRef]

31. Alam, K.J.; Sumon, K.K. Causal Relationship between Trade Openness and Economic Growth: A Panel Data Analysis of Asian Countries. Int. J. Econ. Financ. Issues 2020, 10, 118-126. [CrossRef]

32. Agiomirgianakis, G.; Asteriou, D.; Monastiriotis, V. Human capital and economic growth revisited: A dynamic panel data study. Int. Adv. Econ. Res. 2002, 8, 177-187. [CrossRef]

33. Bassanini, A.; Scarpetta, S. Does human capital matter for growth in OECD countries? A pooled mean-group approach. Econ. Lett. 2002, 74, 399-405. [CrossRef]

34. Yanikkaya, H. Trade openness and economic growth: A cross-country empirical investigation. J. Dev. Econ. 2003, 72, 57-89. [CrossRef]

35. Chen, P.P.; Gupta, R. An investigation of openness and economic growth using panel estimation. Indian J. Econ. 2009, 89, 483.

36. Oketch, M.O. Determinants of human capital formation and economic growth of African countries. Econ. Educ. Rev. 2006, 25, 554-564. [CrossRef]

37. Kasman, A.; Duman, Y.S. CO2 emissions, economic growth, energy consumption, trade and urbanization in new EU member and candidate countries: A panel data analysis. Econ. Model. 2015, 44, 97-103. [CrossRef]

38. Kong, Q.; Peng, D.; Ni, Y.; Jiang, X.; Wang, Z. Trade openness and Economic Growth Quality of China: Empirical Analysis Using ARDL Model. Available online: www.sciencedirect.com/science/article/abs/pii/ S1544612319312565 (accessed on 6 March 2020).

39. Fetahi-Vehapi, M.; Sadiku, L.; Petkovski, M. Empirical analysis of the effects of trade openness on economic growth: An evidence for South East European countries. Procedia Econ. Financ. 2015, 19, 17-26. [CrossRef]

40. Nowbutsing, B.M. The impact of openness on economic growth: Case of Indian Ocean rim countries. J. Econ. Dev. Stud. 2014, 2, 407-427.

41. Adhikary, B.K. FDI, trade openness, capital formation, and economic growth in Bangladesh: A linkage analysis. Int. J. Bus. Manag. 2011, 6, 16. [CrossRef]

42. Bibi, S.; Ahmad, S.T.; Rashid, H. Impact of trade openness, FDI, exchange rate and inflation on economic growth: A case study of Pakistan. Int. J. Account. Financ. Report. 2014, 4, 236. [CrossRef]

43. Vernor, R. International Investment and International Trade in the Product Cycle. Q. J. Econ. 1966, 80, 190-207. [CrossRef]

44. Findlay, R. Growth and development in trade models. In Handbook of International Economics; Jonesn, R., Kenen, P., Eds.; Elsevier Science Publishers: New York, NY, USA, 1984.

45. Hye, Q.M.A.; Lau, W.Y. Trade openness and economic growth: Empirical evidence from India. J. Bus. Econ. Manag. 2015, 16, 188-205. [CrossRef]

46. Karimzadeh, M.; Karimzadeh, B. Impact of trade and Human capital on Economic growth of India: An empirical analysis. Rom. Econ. J. 2013, 48, 201-214.

47. Zhang, C.; Zhuang, L. The composition of human capital and economic growth: Evidence from China using dynamic panel data analysis. China Econ. Rev. 2011, 22, 165-171. [CrossRef]

48. Matousek, R.; Tzeremes, N.G. The asymmetric impact of human capital on economic growth. Available online: https://ink.springer.com/article/10.1007/s00181-019-01789-z\#citeas (accessed on 31 October 2019).

49. Adelakun, O.J. Human capital development and economic growth in Nigeria. Eur. J. Bus. Manag. 2011, 3, 29-38.

50. Adu-Gyamfi, G.; Nketiah, E.; Obuobi, B.; Adjei, M. Trade Openness, Inflation and GDP Growth: Panel Data Evidence from Nine (9) West Africa Countries. Open J. Bus. Manag. 2019, 8, 314-328. [CrossRef]

51. Bajwa, S.; Siddiqi, M.W. Trade openness and its effects on economic growth in selected South Asian countries: A panel data study. World Acad. Sci. Eng. Technol. 2011, 50, 1073-1078.

52. Ijirshar, V.U. Impact of Trade Openness on Economic Growth among ECOWAS Countries: 1975-2017. CBN J. Appl. Stat. 2019, 10, 75-96. [CrossRef]

53. Nguyen, A.T. The Relationship between Trade Openness, Economic Growth, Exchange Rate and Tariff Rate: Evidence from Northeast Asia. Studies 2019, 1, 10-22. [CrossRef]

54. Levin, A.; Lin, C.F.; Chu, C.S.J. Unit root tests in panel data: Asymptotic and finite-sample properties. J. Econom. 2002, 108, 1-24. [CrossRef]

55. Im, K.S.; Pesaran, M.H.; Shin, Y. Testing for unit roots in heterogeneous panels. J. Econom. 2003, 115, 53-74. [CrossRef] 
56. Maddala, G.S.; Wu, S. A comparative study of unit root tests with panel data and a new simple test. Oxf. Bull. Econ. Stat. 1999, 61, 631-652. [CrossRef]

57. Pedroni, P. Critical values for cointegration tests in heterogeneous panels with multiple regressors. Oxf. Bull. Econ. Stat. 1999, 61, 653-670. [CrossRef]

58. Pedroni, P. Panel cointegration: Asymptotic and finite sample properties of pooled time series tests with an application to the PPP hypothesis. Econom. Theory 2004, 20, 597-625. [CrossRef]

59. Kao, C. Spurious regression and residual-based tests for cointegration in panel data. J. Econom. 1999, 90, 1-44. [CrossRef]

60. Al-Mulali, U.; Ozturk, I.; Lean, H.H. The influence of economic growth, urbanization, trade openness, financial development, and renewable energy on pollution in Europe. Nat. Hazards 2015, 79, 621-644. [CrossRef]

61. Salim, R.; Yao, Y.; Chen, G.S. Does human capital matter for energy consumption in China? Energy Econ. 2017, 67, 49-59. [CrossRef]

62. Dumitrescu, E.I.; Hurlin, C. Testing for Granger non-causality in heterogeneous panels. Econ. Model. 2012, 29, 1450-1460. [CrossRef]

63. Arouri, M.E.H.; Youssef, A.B.; Nguyen-Viet, C.; Soucat, A. Effects of Urbanization on Economic Growth and Human Capital Formation in Africa; Science Publishers, Inc.: Hauppauge, NY, USA, 2014.

64. Zheng, W.; Walsh, P.P. Economic growth, urbanization and energy consumption-A provincial level analysis of China. Energy Econ. 2019, 80, 153-162. [CrossRef]

65. Mc Reynald Simbajon Banderlipe, I.I. Call me Maybe: The Impact of Telecommunications on Economic Growth in the Asean Region. Ph.D. Thesis, De La Salle University, Malate, Manila, 2013.

66. Ali, Q.; Khan, M.T.; Khan, M.N. Dynamics between financial development, tourism, sanitation, renewable energy, trade and total reserves in 19 Asia cooperation dialogue members. J. Clean. Prod. 2018, 179, 114-131. [CrossRef]

67. Abdouli, M.; Omri, A. Exploring the Nexus among FDI Inflows, Environmental Quality, Human Capital, and Economic Growth in the Mediterranean Region. J. Knowl. Econ. 2020, 1-23. [CrossRef]

68. Alfaro, L.; Chanda, A.; Kalemli-Ozcan, S.; Sayek, S. How does foreign direct investment promote economic growth? In Exploring the Effects of Financial Markets on; Harvard Business School: Boston, MA, USA, 2006.

(C) 2020 by the authors. Licensee MDPI, Basel, Switzerland. This article is an open access article distributed under the terms and conditions of the Creative Commons Attribution (CC BY) license (http://creativecommons.org/licenses/by/4.0/). 